\title{
Bacterial Apical Necrosis of Mango in Southern Spain: A Disease Caused by Pseudomonas syringae pv. syringae
}

\author{
Francisco M. Cazorla, Juan A. Torés, Laura Olalla, Alejandro Pérez-García, José M. Farré, and Antonio de Vicente
}

First, third, fourth, and sixth authors: Departamento de Microbiología, Facultad de Ciencias, Universidad de Málaga, 29071-Málaga, Spain; and second and fifth authors: Estación Experimental "La Mayora", C.S.I.C., Algarrobo-Costa, 29750-Málaga, Spain.

Accepted for publication 3 April 1998.

\section{ABSTRACT}

Cazorla, F. M., Torés, J. A., Olalla, L., Pérez-García, A., Farré, J. M., and de Vicente, A. 1998. Bacterial apical necrosis of mango in southern Spain: A disease caused by Pseudomonas syringae pv. syringae. Phytopathology 88:614-620.

A necrotic bacterial disease of mango trees (Mangifera indica) in Spain affecting buds, leaves, and stems is described for the first time. Necrosis of flower and vegetative buds on commercial trees during winter dormancy was the most destructive symptom of the disease. The apical necrosis is caused by Pseudomonas syringae, which was always isolated from mango trees with disease symptoms. Of 95 bacterial strains isolated from symptomatic tissues and characterized from 1992 to 1997, over 90\% were identified as $P$. syringae pv. syringae. Additional strains were isolated from healthy mango trees, and they were identical to the isolates from diseased tissues. Pathogenicity tests on mango plants showed that $P$. syringae pv. syringae incited the apical necrosis, but that climatic conditions determined the onset of disease development. Populations of total bacteria and of $P$. syringae and the number of active ice nuclei were monitored over a 3-year period. The largest populations of $P$. syringae were associated with cool, wet periods that coincided with the highest disease severity, whereas $P$. syringae was only occasionally detected on healthy trees. The median effective dose was estimated from infectivity titration assays.
Mango, Mangifera indica L., is grown throughout the tropics and subtropics and is one of the most important fruit crops in the world. India produces $70 \%$ of the world's mangoes, although Mexico is the largest exporter of fresh fruit (22). In Europe, mango orchards are not extensive, but mango plantings in southern Spain have increased over the last 10 years, currently covering about 800 ha. Some bacterial diseases of mango trees caused by Agrobacterium tumefaciens, Bacillus subtilis, Erwinia carotovora subsp. carotovora (1), and Xanthomonas campestris pv. mangiferaeindicae (the most widely known and producer of bacterial black spot of mango fruits) (22) have been previously described.

Apical bud necrosis and leaf spotting have been observed in mango trees of different cultivars grown in southern Spain since 1991 (3). This apical necrosis results in significant economic losses and is one of the primary factors limiting mango fruit production in southern Spain and Portugal (3). Mango buds, leaves, and stems are all susceptible to infection, but fruit lesions have not been observed. Disease symptoms include necrosis of vegetative and flower buds and bud failure before budbreak (Fig. 1). Necrotic lesions in buds sometimes extend to the leaf petiole through the stem. Generally, a white milky gum exudes from necrotic lesions on buds, stems, and less frequently on petioles. Necrotic symptoms also affect flower panicles, causing the most severe economic losses because of the decrease in fruit set. Lesions on leaves start as interveinal, angular, water-soaked spots (1 to $3 \mathrm{~mm}$ in diameter) that may coalesce, becoming black and slightly raised.

Preliminary isolation from diseased tissues of mango with apical necrosis have shown the presence of bacterial strains resembling Pseudomonas syringae, which is a common inhabitant of a large number of plant species, where it may be present in epiphytic or pathogenic association (11). Symptoms similar to those observed in mango have been reported on other species of fruit trees in-

Corresponding author: A. de Vicente; E-mail address: adevicente@uma.es

Publication no. P-1998-0507-03R

(C) 1998 The American Phytopathological Society fected by $P$. syringae pv. syringae (8) such as peach (4), citrus (17), cherry (25), almond (16), and pear (18). In these studies, much attention has been paid to the role of bacterial population sizes and climatic factors in the development of plant damage induced by $P$. syringae, and the likelihood of disease occurrence.

The main objective of this work was to identify and study the role of $P$. syringae as a causal agent of the apical necrosis in mango trees, incorporating the performance of Koch's postulates. This paper reports the characteristics of strains isolated from healthy and diseased tissues, the results of pathogenicity tests, and the environmental conditions that favor the disease. The quantitative relationship between the population size of the pathogen and the disease incidence in Málaga, Spain, is also included.

\section{MATERIALS AND METHODS}

Study area. Commercial orchards in Málaga, Spain, were studied at different locations near the Mediterranean coast (Benajarafe, Estepona, and Torrox) and at a cultivar collection in the Experimental Station "La Mayora" of the Consejo Superior de Investigaciones Científicas (CSIC) in Algarrobo. Weather was monitored at the meteorological station at La Mayora.

Isolation. To isolate the causal agent of apical necrosis, small pieces of affected leaves, buds, and other tissues were cut from the edge of a recent necrotic lesion, placed in sterile plastic bags, transported to the laboratory, and processed on the day of sampling. The samples were processed by two methods. (i) A portion was surface-disinfected by immersion in a sterile aqueous solution of $0.1 \%$ (wt/vol) $\mathrm{HgCl}_{2}$, rinsed in sterile distilled water, and plated on King medium B (KB) (12) and nutrient agar (NA). (ii) The remainder was homogenized in a lab blender for 3 min with $10 \mathrm{ml}$ of sterile phosphate buffer $(0.1 \mathrm{M}, \mathrm{pH}=7.2)$ per $\mathrm{g}$ of fresh plant material, and $100 \mu \mathrm{l}$ was spread onto KB and NA. Plates were incubated at $22^{\circ} \mathrm{C}$ for 2 to 3 days. In addition, colonies of fluorescent pseudomonads were isolated, as described above for the second procedure, from healthy mango trees for comparative studies. 
Identification and characterization of bacterial strains. The bacterial isolates were identified according to biochemical and physiological tests described previously $(1,9,14)$ including Gram stain; metabolism of glucose; nitrate reduction; growth on yeast extract-dextrose-calcium carbonate agar; production of fluorescent pigment; LOPAT tests (levan production, oxidase reaction, potato soft rot, arginine dihydrolase $[\mathrm{ADH}]$, and tobacco hypersensitivity); hydrolysis of gelatin and esculin; and utilization of glucose, mannitol, inositol, adonitol, sorbitol, gluconate, propionate, D-tartrate, L-tartrate, L-lactate, and L-histidine. All inoculated media were incubated at $22^{\circ} \mathrm{C}$ for 3 to 5 days. Duplicate tubes or plates were run for each test, and tests were repeated at least twice.
Ice nucleation activity (INA) of the bacterial isolates was assayed following a tube test previously described by Cazorla et al. (2). Cells from pure cultures grown on KB agar were resuspended $\left(10^{7}\right.$ cells per $\left.\mathrm{ml}\right)$ in sterile phosphate buffer $(0.1 \mathrm{M}, \mathrm{pH}=7.2)$. Three tubes containing each bacterial suspension were immersed at $-5^{\circ} \mathrm{C}$ for $10 \mathrm{~min}$ in a circulating water-ethanol bath.

The ability of the isolated bacterial strains to produce syringomycin and syringopeptin was assayed by growth inhibition tests. Syringomycin production was determined against Geotrichum candidum F-260 (provided by D. C. Gross, Department of Plant Pathology, Pullman, WA) and Rhodotorula pilimanae (provided by N. S. Iacobellis, Univ. Basilicata, Potenza, Italy) using a potato dextrose agar plate assay (7). The production of syringopeptin was
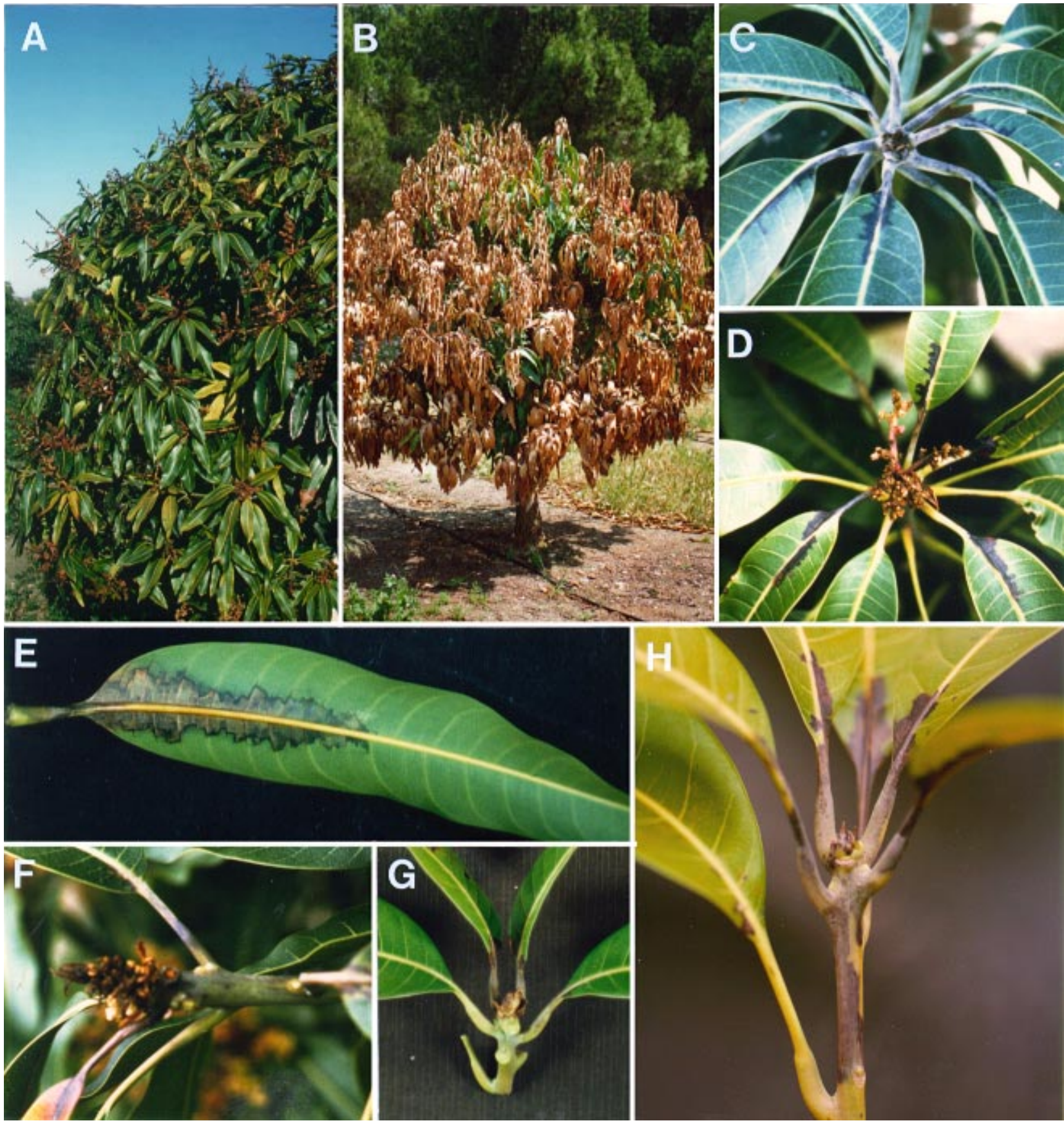

Fig. 1. Typical symptoms of bacterial apical necrosis on mango trees. A, Diseased tree with typical necrosis affecting most flower panicles and $\mathbf{B}$, a tree presenting a stronger attack with a generalized blast. Mango buds, leaves, and stems are susceptible to infection; symptoms include necrosis of $\mathbf{C}$, vegetative and flower buds and D, panicles; and necrotic lesions frequently extend to the leaf petioles and stem. Lesions on leaves start as interveinal necrotic spots, and later, $\mathbf{E}$, they coalesce, become black, and raise slightly. F, Infected dormant buds generally show the initial symptoms. G, A detail of an affected bud is observed from an axial cut. H, When buds were experimentally inoculated with strains of Pseudomonas syringae pv. syringae, typical symptoms were reproduced, and, generally, bud necrosis extended towards stem and leaf petioles. 
assayed by growth inhibition of B. megaterium (provided N. S. Iacobellis) (13).

Several strains of $P$. syringae and $X$. campestris pathovars were used as controls for toxin production and host range tests including $P$. syringae pv. syringae (CECT 127), X. campestris pv. campestris (CECT 97), and X. campestris pv. vesicatoria (CECT 792) obtained from the Spanish Type Culture Collection (C.E.C.T., Valencia, Spain); and P. syringae pv. syringae (NCPPB 4429), $P$. syringae pv. tomato (NCPPB 1106), P. syringae pv. phaseolicola (NCPPB 1103), P. syringae pv. tabaci (NCPPB 1427), P. syringae pv. coronafaciens (NCPPB 1357), and P. syringae pv. tagetis (NCPPB 4430) obtained from the National Collection of Plant Pathogenic Bacteria (N.C.P.P.B., Harpenden, United Kingdom).

Pathogenicity tests. Pathogenicity tests in tomato and lilac plants, immature lemon and pear fruits, and bean pods were performed to confirm the diagnosis of the bacterial strains (14). These assays were repeated three times for each studied strain, and each assay was carried out on five different leaves, fruits, or pods. The fruits were swabbed with alcohol and washed in sterile water. Five drops of inoculum $\left(10^{6} \mathrm{CFU} / \mathrm{ml}\right)$ were placed on the fruit surface (bean pods, lemon, and pear), which was punctured by pricking through the drop with a sterile needle. The inoculated fruits were incubated at $25^{\circ} \mathrm{C}$ in closed boxes lined with damp blotting paper. Tomato and lilac plants with fully expanded leaves were inoculated with a $20-\mu$ drop of the same bacterial suspension $\left(10^{6}\right.$ $\mathrm{CFU} / \mathrm{ml}$ ) that was deposited on a fresh wound made on the midrib of the leaf; each isolate was inoculated on three leaves on separate twigs. After inoculation, the plants were placed in a growth chamber at $22^{\circ} \mathrm{C}$ with a $16 \mathrm{~h}$ (light) $/ 8 \mathrm{~h}$ (dark) photoperiod and covered by transparent polyethylene bags to maintain a high relative humidity. The bags were removed after $48 \mathrm{~h}$ (14). The appearance of infected leaves was recorded after a 7-day incubation period. Reference strains and sterile phosphate buffer were used as controls.

To test the pathogenicity of $P$. syringae pv. syringae isolates on mango, two experiments were carried out beginning in March 1994 and January 1996. Buds of 2-year-old mango plants (cv. Osteen) growing in pots were inoculated with $10 \mu \mathrm{l}$ of a $3 \times 10^{7}-\mathrm{CFU} / \mathrm{ml}$ bacterial suspension in phosphate buffer, and the inoculum was forced into the bud with a microsyringe.

TABLE 1. Physiological and biochemical characteristics identifying the bacterial strains $(n=95)$ isolated from necrotic lesions in buds and leaves of mango trees growing in different localities of Málaga, Spain, from 1991 to 1994

\begin{tabular}{|c|c|c|c|c|}
\hline \multirow[b]{2}{*}{ Test } & \multicolumn{4}{|c|}{ Physiological and biochemical profiles of bacterial isolates } \\
\hline & $\mathrm{Bt} 1^{\mathrm{a}}$ & Bt 2 & Bt 3 & Bt 4 \\
\hline Morphology & Coccobacillus & Coccobacillus & Coccobacillus & Coccobacillus \\
\hline Gram stain & - & - & - & - \\
\hline Fluorescence & + & + & - & - \\
\hline Oxidase & - & + & - & - \\
\hline $\mathrm{ADH}^{\mathrm{b}}$ & - & - & - & - \\
\hline $\begin{array}{l}\text { Glucose } \\
\text { metabolism }^{\mathrm{c}}\end{array}$ & $\mathrm{O}$ & $\mathrm{O}$ & $\mathrm{F}$ & $\mathrm{F}$ \\
\hline$Y^{d}$ & W & W & $\mathrm{Y}$ & $\mathrm{Y}$ \\
\hline INA $^{\mathrm{e}}$ & + & - & - & + \\
\hline $\begin{array}{l}\text { Tobacco } \\
\text { hypersensitivity } \\
\text { Number of }\end{array}$ & + & + & + & $t^{\mathrm{f}}$ \\
\hline isolates $(\%)^{\mathrm{g}}$ & 87 (91.6) & $1(1.1)$ & $4(4.2)$ & $3(3.2)$ \\
\hline Identification & $\begin{array}{c}\text { Pseudomonas } \\
\text { syringae }\end{array}$ & $\begin{array}{l}\text { Pseudomonas } \\
\text { spp. }\end{array}$ & $\begin{array}{l}\text { Erwinia spp./ } \\
\text { Pantoea spp. }\end{array}$ & $\begin{array}{l}\text { Pantoea } \\
\text { agglomerans/ } \\
\text { (formerly } E \text {. } \\
\text { herbicola) }\end{array}$ \\
\hline $\begin{array}{l}\text { a } \mathrm{Bt}=\text { bacterial ty } \\
\text { b Arginine dihydr } \\
\text { c Metabolism of } \\
\text { d Growth on yea } \\
\text { and Y = yellow } \\
\text { e Ice nucleation a } \\
\text { f One strain was } \\
\text { g Number of assa }\end{array}$ & $\begin{array}{l}\text { ype. } \\
\text { rolase. } \\
\text { glucose: } \mathrm{O}=\text { ox } \\
\text { st extract-dextr } \\
\text { mucoid coloni } \\
\text { ctivity. } \\
\text { negative. } \\
\text { yed strains and }\end{array}$ & $\begin{array}{l}\text { idative and } \mathrm{F}= \\
\text { ose-calcium car } \\
\text { s. } \\
\text { percentage of to }\end{array}$ & $\begin{array}{l}\text { ermentative. } \\
\text { onate agar: } \mathrm{W}\end{array}$ & white colonies \\
\hline
\end{tabular}

In the first experiment (spring 1994), bacterial suspensions of 12 strains of $P$. syringae pv. syringae (eight isolated from diseased mango trees and four isolated from asymptomatic mango buds), a strain of Pantoea spp. isolated from mango trees, and a strain of $P$. syringae pv. tomato isolated from tomato in Málaga were each injected into six buds of different mango plants; generally, each plant had only one bud. Sterile phosphate buffer was used as a control. The trees were maintained under field conditions at $\mathrm{La}$ Mayora from March to May 1994; during the test, the average temperature was $17^{\circ} \mathrm{C}$ with a minimum temperature of $8^{\circ} \mathrm{C}$, and rainfall totaled $50 \mathrm{~mm}$.

In the second experiment, 60 mango plants (cv. Osteen) growing in pots were subdivided into three groups of 20; two groups were maintained under field conditions in two different sites with different wind exposures at La Mayora and the third was kept in a plastic greenhouse. Each of the four buds of each group was inoculated with one of the four $P$. syringae pv. syringae strains (three isolated from diseased mango tissues and one isolated from a symptomless mango tree), and sterile phosphate buffer served as a control. The frequency of occurrence of apical necrosis symptoms on inoculated buds was recorded after 3 and 6 weeks. During this second assay (January to March 1996), the average field temperature was $13^{\circ} \mathrm{C}$ with a minimum temperature of $3.5^{\circ} \mathrm{C}$, and rainfall totaled $293 \mathrm{~mm}$. Conditions in the greenhouse averaged $18^{\circ} \mathrm{C}$ with a minimum temperature always over $10^{\circ} \mathrm{C}$, a relative humidity of 60 to $80 \%$, and no wetting of leaves.

To confirm the presence of $P$. syringae in inoculated tissues, reisolation was carried out from plant buds showing necrotic symptoms after 3 or 6 weeks. Each bud was surface-disinfected with $70 \%$ ethanol, cut into small pieces, and homogenized in a lab blender for 3 min with sterile phosphate buffer $(0.1 \mathrm{M}, \mathrm{pH}=7.2)$. Tenfold dilutions of the suspensions were then plated onto $\mathrm{KB}$, and colonies were counted after 3 days of incubation at $22^{\circ} \mathrm{C}$. The identity of bacterial isolates was verified by Gram staining, fluorescent pigment production, LOPAT, and INA tests, as described above.

Estimation of bacterial populations on mango leaves and buds. From 1991 to 1994, an orchard of mango trees growing at La Mayora was surveyed to determine the occurrence and distribution of $P$. syringae. On the basis of previous information, the trees were classified as having repeated outbreaks of apical necrosis over several years (25 trees, group A), or as never or only occasionally affected (14 trees, group B). Bulked samples of five buds were randomly collected from each tree included in this study, regardless of the diseased or symptomless aspect of the buds. Bacterial counts obtained from each bulked sample were converted to the $\log _{10}$, and then the mean of the logs from different trees of each group was calculated to estimate the bacterial populations in buds in the two groups. In the same fashion, leaf samples were collected. Ten milliliters of sterile phosphate buffer was added per gram fresh weight of plant material, and the pieces were homogenized in a lab blender for $3 \mathrm{~min}$. Then, $100 \mu \mathrm{l}$ of 10 -fold serial dilutions was plated onto NA and $\mathrm{KB}$; cycloheximide $(100 \mu \mathrm{g} / \mathrm{ml})$ was added to both media to prevent fungal growth (19). Plates were incubated at $22^{\circ} \mathrm{C}$ for 2 to 3 days. Total bacterial populations were estimated from NA counts. Colonies on KB that were fluorescent under UV light were tested for presence of oxidase and ADH, and populations of $P$. syringae were estimated from colonies that were fluorescent, oxidase negative, and ADH negative.

The number of ice nuclei active on mango tissues was estimated following a multiple-tube ice nucleation test described in a previous work (2). Triplicate 10-fold serial dilutions of the homogenized samples were carried out in tubes containing $9 \mathrm{ml}$ of sterile phosphate buffer and, subsequently, the tubes were immersed for $10 \mathrm{~min}$ in a circulating water-ethanol bath maintained at $-5^{\circ} \mathrm{C}$ and, in a second trial, at $-9^{\circ} \mathrm{C}$. The number of frozen tubes at a given temperature was recorded for each dilution, and the number of ice nuclei per gram fresh weight was estimated in terms of the most probable number (2). 
Assessment of disease incidence. Disease incidence from December 1992 to June 1994 was determined in situ as the proportion of diseased vegetative buds per tree. Generally, diseased buds appeared with the scales opened and with necrosis affecting the internal and external bractea, extending frequently to the stem. Forty mango trees located at La Mayora were surveyed. The assay was performed with individually selected healthy and diseased trees, and results of each studied tree were independently obtained and considered. Twenty randomly selected buds per tree were examined, and the number of diseased buds was recorded in every sampling.

Infectivity titration assay. Experiments to estimate the median effective dose $\left(\mathrm{ED}_{50}=\right.$ number of bacteria sufficient to induce disease in $50 \%$ of the inoculated buds) required to incite apical necrosis were performed and conducted under field conditions using four strains of $P$. syringae pv. syringae (three isolated from mango trees with apical necrosis symptoms and one from a symptomless mango tree). Inoculations of buds with bacterial suspensions of different cell densities $\left(10^{2}\right.$ to $10^{7} \mathrm{CFU}$ per bud) were carried out as described previously for pathogenicity tests. Five suspensions of each strain at different bacterial concentrations were prepared, and five buds were inoculated with each bacterial suspension (each inoculum dose of each strain). The number of buds with disease symptoms was recorded after 6 weeks. Ten buds were inoculated with sterile buffer as a control. A dose response curve was produced by plotting the bacterial dose ( $\log _{10}$-transformed) against a Weibull transformation of the proportion of diseased buds $\left(\log _{10}\left[-\log _{\mathrm{e}}(1-\mathrm{R})\right]\right)$. A straight line was fitted to the data points that were not equal to a 0 or $100 \%$ response (24).

\section{RESULTS}

Bacterial isolation, identification, and characterization. Isolations from diseased mango tissues yielded almost pure cultures of translucent bacterial colonies that were fluorescent on $\mathrm{KB}$ under UV light after 48 to $72 \mathrm{~h}$ of incubation at $22^{\circ} \mathrm{C}$. Ninety-five separate bacterial colonies were selected and purified on $\mathrm{KB}$ and NA for further analysis. Eighty-eight fluorescent colonies were isolated from affected tissues, and seven isolates were considered to belong to other bacterial types. The fluorescent strains showed similar biochemical and physiological characteristics that were typical of $P$. syringae (Table 1$)$. The characteristics of the $P$. syringae strains isolated from diseased mango trees $(n=87)$ were similar to those of $P$. syringae strains $(n=18)$ isolated from healthy mango trees (Table 2). All of the isolates from asymptomatic and diseased mango tissues were identified as $P$. syringae pv. syringae $(6,9,20$, 26). Nearly all the isolates had ice nucleation activity at $-5^{\circ} \mathrm{C}$, and all the strains tested were also able to produce syringomycin and syringopeptin, as demonstrated by the inhibition of G. candidum F-260, $R$. pilimanae, and B. megaterium.

$P$. syringae strains isolated from diseased and healthy mango tissues induced typical symptoms of $P$. syringae pv. syringae on inoculated immature lemon and pear fruits, appearing as deep, black necrotic pits on lemons and dark necrotic spots on pears. Many strains produced water-soaked lesions with a reddish margin on dwarf bean pods, although they did not produce disease symptoms. In leaves of lilac and tomato inoculated by pricking, necrotic areas were seen 4 days after inoculation.

Pathogenicity on mango plants. Twelve strains of $P$. syringae pv. syringae isolated from diseased and healthy mango trees in different locations were individually inoculated onto healthy buds and shoots of mango plants to test for pathogenicity. All strains produced similar symptoms on inoculated buds and caused typical symptoms of apical necrosis as described above (Fig. 1H). On shoots, the first symptoms appeared 6 to 7 days after inoculation. Necrotic symptom development was never observed when buds were inoculated with $P$. syringae pv. tomato, Pantoea spp., or buffer.

Two pathogenicity experiments were carried out under different environmental conditions. In the first test performed under field conditions during the spring, a higher proportion of inoculated buds remained healthy up to 35 days after inoculation (80.6\%), compared with the second test, which was carried out during winter $(18.7 \%)$ and also performed under field conditions. This second period was characterized by lower temperatures and more abundant rainfall. Typical necrotic symptoms were observed in most of the inoculated buds after 3 and 6 weeks, and the first symptoms were observed 7 days after inoculation. In buffer-inoculated controls, no necrotic lesions around the inoculation sites were observed after 6 weeks. In a parallel assay carried out in a plastic greenhouse, the symptom development in inoculated mango buds was lower (31.2\% after 3 weeks and $43.8 \%$ after 6 weeks) than in field conditions ( $71.9 \%$ after 3 weeks and $81.3 \%$ after 6 weeks). No differences in symptom development were observed between different $P$. syringae pv. syringae strains.

Bacterial strains were reisolated from the inoculated buds that developed typical symptoms. Reisolation yielded fluorescent bacteria with characteristics similar to the inoculated isolates; the presence of $P$. syringae pv. syringae was confirmed in $92.5 \%$ of experimentally inoculated mango buds showing apical necrosis symptoms 6 weeks after inoculation. Furthermore, $P$. syringae cells were present in high numbers in bud tissues $\left(10^{7}\right.$ to $10^{8}$ $\mathrm{CFU} / \mathrm{g}$ fresh weight) that developed symptoms.

Bacterial populations on mango trees. The total number of bacteria isolated from mango buds was similar in healthy and diseased trees $\left(10^{4}\right.$ to $10^{8} \mathrm{CFU} / \mathrm{g}$ fresh weight) over the entire period

TABLE 2. Characterization and identification of Pseudomonas syringae strains isolated from healthy $(n=18)$ and diseased $(n=87)$ mango trees in Málaga, Spain ${ }^{a}$

\begin{tabular}{|c|c|c|c|}
\hline & $\begin{array}{c}\text { Bacterial } \\
\text { isolates from } \\
\text { liseased tissues }\end{array}$ & $\begin{array}{c}\text { Bacterial } \\
\text { isolates from } \\
\text { healthy tissues }\end{array}$ & $\begin{array}{c}\text { P. syringae pv. } \\
\text { syringae } \\
(6,9,20,26)\end{array}$ \\
\hline \multicolumn{4}{|l|}{ LOPAT tests } \\
\hline Levan & $+^{\mathrm{b}}$ & + & + \\
\hline Oxidase & $-^{\mathrm{c}}$ & - & - \\
\hline Potato soft rot & - & - & - \\
\hline Arginine dihydrolase & - & - & - \\
\hline Tobacco hypersensitivity & + & + & + \\
\hline \multicolumn{4}{|l|}{ Hydrolysis of } \\
\hline Gelatin & + & + & + \\
\hline Esculin & + & + & + \\
\hline \multicolumn{4}{|l|}{ Utilization of } \\
\hline Glucose & + & + & + \\
\hline Mannitol & + & + & + \\
\hline Inositol & + & + & + \\
\hline Adonitol & + & + & + \\
\hline Sorbitol & + & + & + \\
\hline Gluconate & + & + & + \\
\hline Propionate & + & + & + \\
\hline D-tartrate & $V(-)^{d}$ & $\mathrm{~V}(-)$ & $\mathrm{V}(-)$ \\
\hline L-tartrate & - & - & - \\
\hline L-lactate & + & + & + \\
\hline L-histidine & + & + & + \\
\hline Ice nucleation activity & + & + & + \\
\hline \multicolumn{4}{|l|}{ Production of } \\
\hline Syringomycin & + & + & + \\
\hline Syringopeptin & + & + & + \\
\hline \multicolumn{4}{|l|}{ Pathogenicity on } \\
\hline Tomato & + & + & + \\
\hline Lilac & + & + & + \\
\hline Pear fruits & + & + & + \\
\hline Lemon fruits & + & + & + \\
\hline Bean pods & - & - & - \\
\hline
\end{tabular}

a All the strains were rod-shaped Gram-negative bacteria with oxidative assimilation of glucose, production of fluorescent pigments, and absence of nitrate reduction.

b $+=85 \%$ or more strains are positive.

c $-=85 \%$ or more strains are negative.

${ }^{\mathrm{d}} \mathrm{V}(-)=15$ to $50 \%$ of strains are positive 
studied (Fig. 2). P. syringae collected from diseased mango trees accounted for more than $90 \%$ of the total bacterial population in some instances (Fig. 2A). However, P. syringae was only occasionally detected in buds of healthy trees (Fig. 2B). Among symptomatic trees showing disease symptoms from December 1992 to June 1994, more than $80 \%$ of samples exceeded $10^{6}$ CFU of $P$. syringae per $\mathrm{g}$ fresh weight, and the mean population level of $P$. syringae for the whole period of study was $6.17 \times 10^{6} \mathrm{CFU} / \mathrm{g}$ fresh weight. In the trees that had never or only occasionally been infected, only $5 \%$ of samples reached $10^{5} \mathrm{CFU}$ of $P$. syringae per $\mathrm{g}$ fresh weight, and the mean population of $P$. syringae was $7.76 \times 10^{0}$ $\mathrm{CFU} / \mathrm{g}$ fresh weight (Fig. 2). Bacterial populations fluctuated in a cyclic manner, gradually increasing during the cool, wet autumn and winter months and decreasing during the warm, dry spring and summer months. Leaves had lower bacterial populations $\left(10^{3}\right.$ to $10^{5} \mathrm{CFU} / \mathrm{g}$ fresh weight) than did buds (data not shown).

The number of ice nuclei active at -5 and $-9^{\circ} \mathrm{C}$ was also determined on buds of mango trees. INA was generally detected and values were related to the numbers of $P$. syringae in affected trees, but the numbers of ice nuclei per gram fresh weight active at $-9^{\circ} \mathrm{C}$ were one to two orders of magnitude lower than the number of $P$. syringae $\mathrm{CFU}$ per gram, and the numbers of ice nuclei per gram fresh weight active at $-5^{\circ} \mathrm{C}$ were two to three orders of magnitude lower than $P$. syringae populations (data not shown). In nonaffected trees, in which $P$. syringae was only occasionally detected, ice nuclei were not observed.

Disease incidence in relation to populations of $\boldsymbol{P}$. syringae. In 40 healthy and diseased trees, the incidence of apical necrosis was studied in relation to populations of $P$. syringae. Disease incidence was higher in cool, wet seasons (autumn and winter) and lower in warm seasons (spring and summer) and was more severe during winter in trees that previously harbored high populations of $P$. syringae (Fig. 3). Close associations between the presence of the pathogen and the disease were observed within each group of trees (healthy versus diseased). Similar results were observed for trees belonging to the same group; one of them encompassing diseased trees with noticeable symptoms and high populations of $P$. syringae and another including healthy trees with only low and occasional apical necrosis and populations of $P$. syringae. Trees colonized by $P$. syringae showed high levels of disease incidence (Fig. 3A), whereas noncolonized trees were affected only occasionally (Fig. 3C). During the study, some nonaffected and noncolonized trees (Fig. 3B) were colonized by $P$. syringae and manifested disease symptoms the following autumn.

Infectivity titration assay. The independent-action model has been used in the analysis of the probability of disease response as a function of bacterial dose size (Fig. 4). The median effective dose $\left(\mathrm{ED}_{50}\right)$ was estimated from the straight line produced by adjusting the bacterial-inoculated dose ( $\log _{10}$-transformed) against the response data on a Weibull scale obtained from 11 assays $(r=$ $0.866, P<0.001)$; the estimated $\mathrm{ED}_{50}$ was $6.84 \times 10^{4} \mathrm{CFU}$ of $P$. syringae per bud. After inoculation of three bacterial doses of nearly $10^{2} \mathrm{CFU}$ of $P$. syringae per bud, the five buds remained healthy, and after inoculation of six doses higher than $10^{6} \mathrm{CFU}$ per bud, the five inoculated buds developed symptoms; these response data were discarded to fit the straight line.

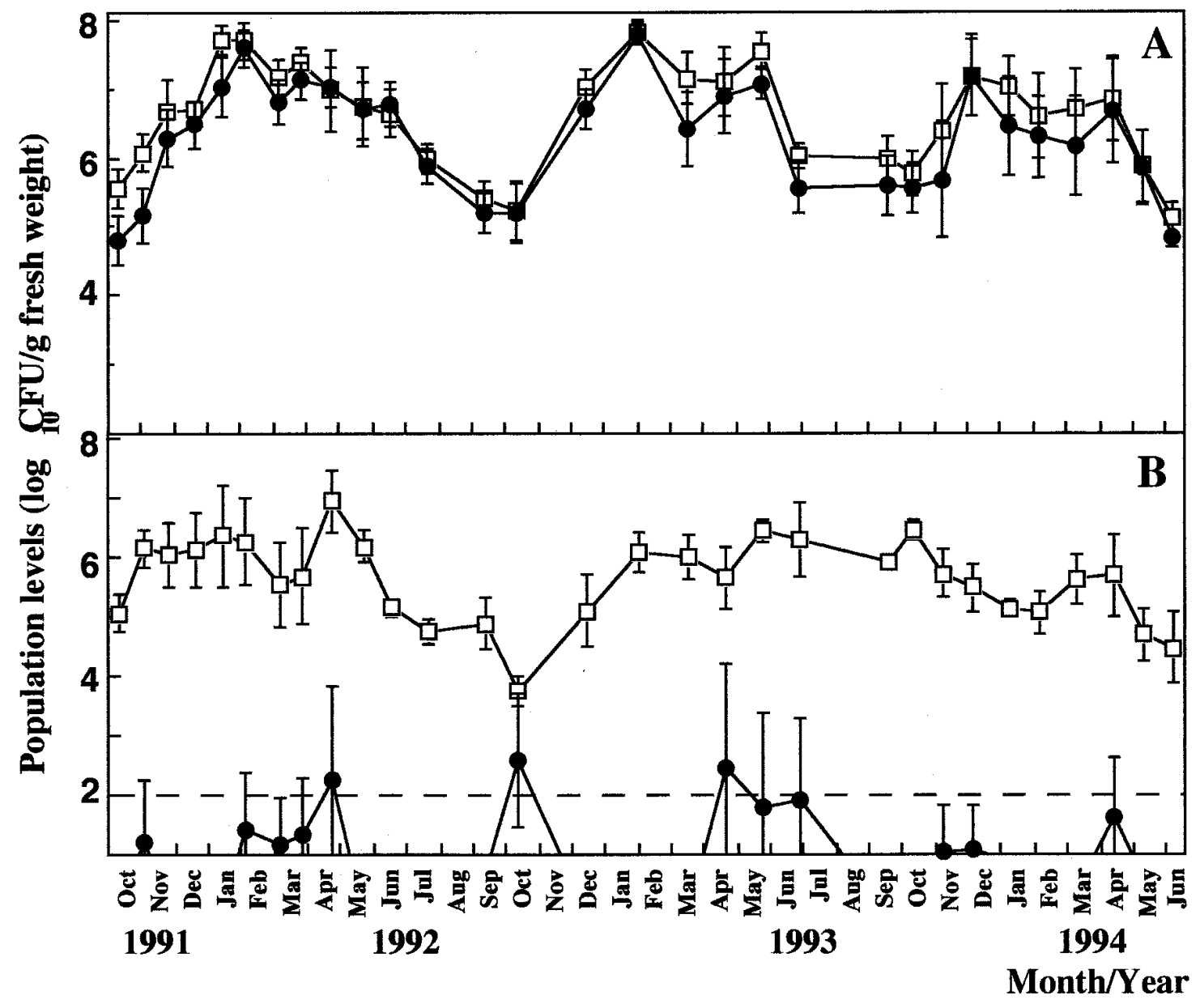

Fig. 2. Populations sizes of total bacteria $(\square)$ and Pseudomonas syringae (•) in bulked samples of five buds from each mango tree growing at La Mayora (arithmetic mean of $\log _{10}$-transformed colony counts \pm [standard deviation/2] of $n$ studied trees). The studied trees were divided into two groups: A, affected trees having previous outbreaks of bacterial apical necrosis $(n=25)$; and $\mathbf{B}$, nonaffected trees without previously known outbreaks or symptoms $(n=14)$. The lowest detectable population level from each sample was $100 \mathrm{CFU} / \mathrm{g}$ fresh weight. 


\section{DISCUSSION}

Bacterial apical necrosis is a new disease of mango characterized by a rapid expansion of necrotic lesions in buds and leaves. It is caused by $P$. syringae pv. syringae. This pathogen usually produces blossom blast and leaf necrosis from autumn to spring, but blast of dormant buds is the most destructive phase of the disease in Spanish growing areas. This bacterium has not been previously reported as a pathogen of mangoes; however, a disease of mango showing similar symptoms has recently been reported in Israel (bacterial black blight), although the causal agent has not been conclusively identified (21). Similar diseases have been reported in other fruit trees $(4,8,17,18,25)$.

Fluorescent pseudomonads isolated from diseased mango tissues were conclusively identified as $P$. syringae pv. syringae on the basis of their nutritional and biochemical profiles. Characteristics were identical to other reports of $P$. syringae pv. syringae $(6,9,20,26)$ including production of the phytotoxins syringomycin and syringopeptin (7), INA, and a host range typical of the pathovar syringae (14). The isolates of $P$. syringae from healthy mango trees were essentially identical to the isolates from diseased tissues.

The role of $P$. syringae pv. syringae strains in the induction of bacterial apical necrosis of mangoes was demonstrated by the production of typical symptoms following inoculation of different isolates into buds of young mango plants and the subsequent reisolation of $P$. syringae pv. syringae from the affected buds $(92.5 \%)$. Symptom development in inoculated buds was strongly influenced

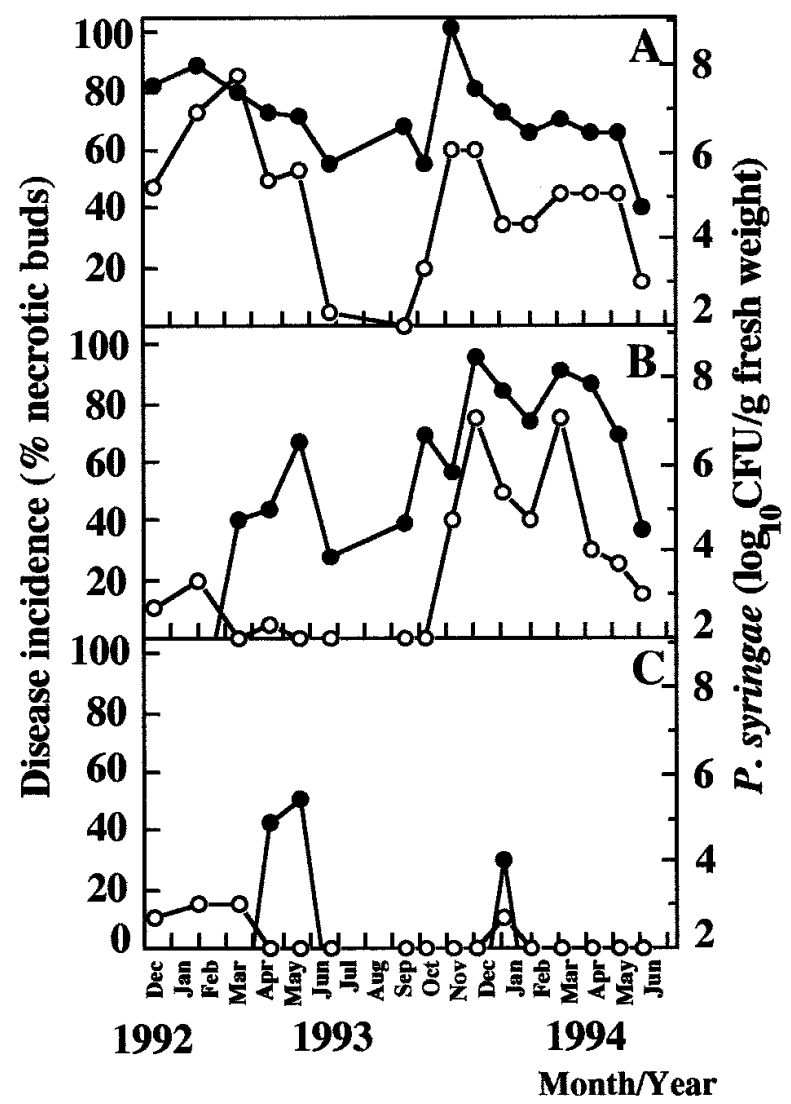

Fig. 3. Population sizes of Pseudomonas syringae (•) and disease incidence (O) on buds of three individual mango trees with different histories of disease incidence. A, Tree number 97 showed disease symptoms at the beginning of this study; B, tree number 72 was initially considered a healthy tree, but developed symptoms during the study; and $\mathbf{C}$, tree number 7 was considered a healthy tree and remained asymptomatic. In each tree, the disease incidence corresponds to the proportion of 20 buds that showed bacterial apical necrosis symptoms, and the $P$. syringae populations were estimated from bulked samples of five buds. by environmental conditions. When the temperature was relatively low and the weather was rainy and wet, there was a higher proportion of buds that became symptomatic. In the same way, apical necrosis in mango trees is frequently observed from late October to March and reaches its maximum development during January (3), which is the cool, wet season in southern Spain. Likewise, the bacterial population sizes were the lowest in all the studied trees during summer under warm, dry climatic conditions.

The study of bacterial populations on mango trees suggests that a large number of $P$. syringae could be an important factor in initiating the development of apical necrosis. The population of $P$. syringae on mango buds and leaves can be the source of inoculum for infection, as it has been proposed in other species $(10,23)$. Affected and healthy trees support similar densities of total bacteria on buds and leaves. However, on affected trees, more than $90 \%$ of the bacterial populations are always comprised of $P$. syringae pv. syringae, whereas on healthy trees, $P$. syringae pv. syringae was only occasionally detected and at low levels. Likewise, in strongly affected mango trees with permanently high levels of $P$. syringae on buds, a severe incidence of disease was observed, except during summer; whereas in symptomless trees with similar densities of total bacteria, $P$. syringae pv. syringae was only occasionally isolated. The high levels of $P$. syringae observed in diseased trees could also be explained by the bacterial growth on infected buds coincident with the disease development, because infested buds were incorporated in bulked samples. However, some trees that were healthy at the beginning of experiment and were not initially colonized by $P$. syringae pv. syringae became infected in spring, developing disease symptoms the following autumn. In this way, it has been reported that the establishment of large epiphytic population sizes of $P$. syringae pv. syringae is necessary for the likelihood of occurrence of bacterial brown spot of snap bean $(10,15)$, and symptoms of different diseases caused by pathovars of $P$. syringae do not appear until some leaves or leaflets are found to harbor relatively high $P$. syringae populations $(15,23)$. Our results support the view that $P$. syringae is a weak pathogen causing disease only when the host is stressed (8).

Other factors could be involved in the initiation of disease such as rain or dew, which are essential for the redistribution of inoculum to other buds and leaves, and wind, which will enhance disease development causing microwounds. Although where the infection starts is not well known yet, natural openings could be possible points of entry. Bacterial populations on mango leaves were lower

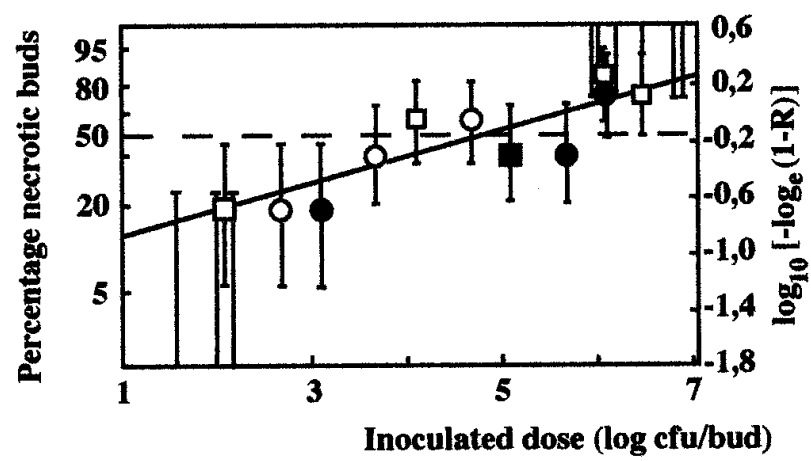

Fig. 4. Relationship between the percentage of buds that developed necrotic symptoms and the number of Pseudomonas syringae cells inoculated per bud (five buds per dose and strain). Four strains of $P$. syringae pv. syringae were employed in this assay: UMAF0005 ( $\square$ ), UMAF0048 (•), and UMAF0049 $(\boldsymbol{\square})$ isolated from diseased mango tissues, and UMAF0069 (O) isolated from a healthy mango tree. The results were recorded after 6 weeks under cool, wet field conditions. The inoculated dose is plotted (on a log scale) against the response proportion of necrotic buds in a Weibull scale on the right; also, the corresponding values of the percentage of response are shown on the left scale. Confidence limits $(50 \%)$ corresponding to a sample size of five buds are shown. 
than on buds, and leaves were generally infected via the petiole from stems infections resulting from initial outbreaks on buds or shoots.

The median effective dose $\left(\mathrm{ED}_{50}\right)$ determined in the infectivity titration experiments was higher than $10^{4} \mathrm{CFU}$ of $P$. syringae pv. syringae per bud; these values were similar to those reported by Ercolani (5) for infectivity titration curves of different pathovars of $P$. syringae multiplying and inducing symptoms in plants different from their natural hosts. For these interactions, a cooperative action of bacterial cells to induce symptoms has been suggested, following the introduction of heavy doses of inoculum into the plant (5).

\section{ACKNOWLEDGMENTS}

This work was partially supported by grants from Consejería de Educación y Ciencia, Junta de Andalucía (Grupo AGR-0169). We thank J. M. Hermoso for information on the disease, helpful assistance, and field work facilities; and V. E. Durán for assistance in pathogenicity and infectivity titration assays. We also thank G. Sanders, D. C. Gross, and N. S. Iacobellis for supplying reference strains; and J. Murillo and E. Montesinos for their suggestions and critically reading the manuscript.

\section{LITERATURE CITED}

1. Bradbury, J. F. 1986. Guide to Plant Pathogenic Bacteria. CAB International Mycological Institute, Slough, United Kingdom.

2. Cazorla, F. M., Olalla, L., Torés, J. A., Pérez-García, A., Codina, J. C., and de Vicente, A. 1995. A method for estimation of population densities of ice nucleating active Pseudomonas syringae in buds and leaves of mango. J. Appl. Bacteriol. 79:341-346.

3. Cazorla, F. M., Torés, J. A., de Vicente, A., and Farré, J. M. 1992. Procesos necróticos de mango: Aislamiento de Pseudomonas syringae. Bol. Cultivos Trop. 92(6):8.

4. Endert, E., and Ritchie, D. F. 1984. Overwintering and survival of Pseudomonas syringae pv. syringae and symptom development in peach trees. Plant Dis. 68:468-470.

5. Ercolani, G. L. 1973. Two hypotheses on the aetiology of response of plants to phytopathogenic bacteria. J. Gen. Microbiol. 74:83-95.

6. Gardan, L., Cottin, S., Bollet, C., and Hunault, G. 1991. Phenotypic heterogeneity of Pseudomonas syringae van Hall. Res. Microbiol. 142: 995-1003.

7. Gross, D. C., and De Vay, S. E. 1977. Production and purification of syringomycin, a phytotoxin produced by a Pseudomonas syringae. Physiol. Plant Pathol. 11:13-28.

8. Hattingh, M. J., Roos, I. M. M., and Mansvelt, E. L. 1989. Infection and systemic invasion of deciduous fruit trees by Pseudomonas syringae in South Africa. Plant Dis. 73:784-789.

9. Hildebrand, D. C., Schroth, M. N., and Sands, D. C. 1988. Pseudomonas. Pages 60-80 in: Laboratory Guide for Identification of Plant
Pathogenic Bacteria, 2nd ed. N. W. Schaad, ed. The American Phytopathological Society, St. Paul, MN.

10. Hirano, S. S., Clayton, M. K., and Upper, C. D. 1994. Estimation of and temporal changes in means and variances of populations of Pseudomonas syringae on snap bean leaflets. Phytopathology 84:934-940.

11. Hirano, S. S., and Upper, C. D. 1983. Ecology and epidemiology of foliar bacterial plant pathogens. Annu. Rev. Phytopathol. 21:243-269.

12. King, E. D., Ward, M. K., and Raney, D. E. 1954. Two simple media for the demonstration of pyocyanin and fluorescein. J. Lab. Clin. Med. 44: 301-307.

13. Lavermicocca, P., Iacobellis, N. S., and Simmaco, M. 1997. Comparison of biological activities of Pseudomonas syringae pv. syringae toxins. Pages 176-181 in: Pseudomonas syringae Pathovars and Related Pathogens. K. Rudolph, T. J. Burr, J. W. Mansfield, D. Stead, A. Vivian, and J. von Kietzell, eds. Kluwer Academic, Dordrecht, the Netherlands.

14. Lelliott, R. A., and Stead, D. E. 1987. Methods in Plant Pathology, Vol. 2: Methods for the Diagnosis of Bacterial Diseases of Plants. Blackwell Scientific Publications, Oxford.

15. Lindemann, J., Arny, D. C., and Upper, C. D. 1984. Use of an apparent infection threshold population of Pseudomonas syringae to predict incidence and severity of brownspot of bean. Phytopathology 74:1334-1339.

16. Lindow, S. E., and Connell, J. H. 1984. Reduction of frost injury to almond by control of ice nucleation active bacteria. J. Am. Soc. Hortic. Sci. 109:48-53.

17. Lopez, M. M. 1989. Bacteriosis de los cítricos debidas a Pseudomonas y Xanthomonas. Fruticult. Prof. 25:69-75.

18. Montesinos, E., and Vilardell, P. 1991. Relationships among population levels of Pseudomonas syringae, amount of ice nuclei, and incidence of blast of dormant flower buds in commercial pear orchards in Catalunya, Spain. Phytopathology 81:113-119.

19. Olive, J. W., and McCarter, S. M. 1988. Occurrence and nature of ice nucleation-active strains of Pseudomonas syringae on apple and peach trees in Georgia. Plant Dis. 72:837-843.

20. Palleroni, N. J. 1984. Pseudomonadaceae. Pages 141-199 in: Bergey's Manual of Systematic Bacteriology. Vol. 1. N. R. Krieg and J. G. Holt, eds. Williams and Wilkins, Baltimore, MD.

21. Pinkas, Y., Maymon, M., and Smolewich, Y. 1996. Bacterial black blight of mango. Alon Hanotea 50:475.

22. Ploetz, R. C., Zentmyer, G. A., Nishijima, W. T., Rohrbach, K. G., and Ohr, H. D., eds. 1994. Compendium of Tropical Fruit Diseases. The American Phytopathological Society, St. Paul, MN.

23. Rouse, D. I., Nordheim, E. V., Hirano, S. S., and Upper, C. D. 1985. A model relating the probability of foliar disease incidence to the population frequencies of bacterial plant pathogens. Phytopathology 75:505-509.

24. Shortley, G., and Wilkins, J. R. 1965. Independent-action and birth-death models in experimental microbiology. Bacteriol. Rev. 29:102-141.

25. Sundin, G. W., Jones, A. L., and Fulbright, D. W. 1989. Copper resistance in Pseudomonas syringae pv. syringae from cherry orchards and its associated transfer in vitro and in planta with a plasmid. Phytopathology 79:861-865

26. Young, J. M., and Triggs, C. M. 1994. Evaluation of determinative tests for pathovars of Pseudomonas syringae van Hall 1902. J. Appl. Bacteriol. 77:195-207. 